\section{Faktor Fundamental Terhadap Tingkat Underpricing Perusahaan Yang Melakukan Initial Public Offering (IPO)}

\author{
Muhani, Nia Eka Pramelia, Molina
}

Fakultas Ekonomi dan Bisnis, Universitas Nasional

Jakarta, Indonesia
JMSAB 167

\begin{abstract}
This study aims to find out the influence of debt to equity ratio, return on asset, return on equity and firm size on the level of underpricing in companies that conduct an Initial Public Offering (IPO) in Indonesia Stock Exchange period 2014-2019. The population in this study is all companies that conducted an Initial Public Offering (IPO) in Indonesia Stock Exchange period 2014-2019. Determination of the sample using a purposive sampling method through certain criteria in order to obtain a sample of 115 companies. The analysis method used in this study was multiple linear regression method. The results showed that: (1) debt to equity ratio has positive and insignificant effect on the level of underpricing; (2) return on asset has negative and significant effect on the level of underpricing; (3) return on equity has negative and insignificant effect on the level of underpricing; and (4) firm size has negative and significant effect on the level of underpricing.
\end{abstract}

\section{Keywords:}

Underpricing, debt to equity ratio, return on asset, return on equity, firm size

\section{Corresponding Author: \\ Muhani}

Fakultas Ekonomi dan Bisnis, Universitas Nasional

Email:muhani@civitas.unas.ac.id

(C) The Author(s) 2020

DOI: https://doi.org/10.36407/jmsab.v3i2.xxx
Received: 15 Aug 2020

Accepted: 26 Sept 2020

Online: 29 Dec 2020

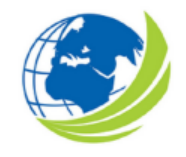

Jurnal Manajemen Strategi dan Aplikasi Bisnis, Vol 3, No. 2, 2020, pp. $171-184$

eISSN 2655-237X

\title{
(C)
}

CC BY: This license allows reusers to distribute, remix, adapt, and build upon the material in any medium or format, so long as attribution is given to the creator. The license allows for commercial use. 


\section{PENDAHULUAN}

Setiap perusahaan memiliki keinginan untuk dapat mengembangkan usahanya dalam upaya menghadapi persaingan yang semakin ketat. Agar perusahaan dapat mengembangkan usahanya, dibutuhkan dana tambahan yang cukup besar yang seringkali tidak dapat dipenuhi jika hanya mengandalkan dana yang berasal dari dalam perusahaan. Perusahaan dapat memperoleh pendanaan dari luar perusahaan sebagai alternatif lainnya yaitu dengan melakukan penawaran saham ke publik melalui pasar modal atau go public. Saham perusahan yang go public akan ditawarkan terlebih dahulu kepada publik di pasar perdana untuk pertama kalinya atau dikenal dengan Initial Public Offering (IPO).

Pertumbuhan jumlah perusahaan yang melakukan IPO di Indonesia semakin meningkat disetiap tahunnya. Bursa Efek Indonesia mencatat pertumbuhan perusahaan yang melakukan IPO mengalami peningkatan setelah tahun 2017. Meskipun jumlah IPO mengalami peningkatan, hal ini tak luput dari fenomena underpricing yang masih sering terjadi pada sebagian besar perusahaan yang melakukan IPO. Tabel berikut menunjukkan jumlah perusahaan yang melakukan IPO di Indonesia tahun 2014-2019.

Tabel 1. Perkembangan Jumlah IPO di Indonesia Tahun 2014-2019

\begin{tabular}{llcccc}
\hline Tahun & $\begin{array}{l}\text { Jumlah } \\
\text { IPO }\end{array}$ & Underpricing & $\begin{array}{l}\text { Persentase } \\
\text { Underpricing }\end{array}$ & Overpricing & \multicolumn{1}{c}{ Tetap } \\
\hline 2014 & 24 & 19 & $79,17 \%$ & 5 & 0 \\
2015 & 18 & 10 & $55,56 \%$ & 6 & 2 \\
2016 & 16 & 13 & $81,25 \%$ & 2 & 1 \\
2017 & 37 & 24 & $64,86 \%$ & 13 & 0 \\
2018 & 57 & 52 & $91,23 \%$ & 5 & 0 \\
2019 & 55 & 48 & $87,27 \%$ & 7 & 0 \\
\hline Jumlah & $\mathbf{2 0 7}$ & $\mathbf{1 6 6}$ & $\mathbf{8 0 , 1 9 \%}$ & $\mathbf{3 8}$ & $\mathbf{3}$ \\
\hline
\end{tabular}

Sumber: Data sekunder diolah, 2020

Berdasarkan Tabel 1 dapat diketahui bahwa dari 207 perusahaan yang melakukan IPO di tahun 2014-2019, terdapat 166 perusahaan yang mengalami underpricing atau sebesar 80,19\%, dengan 38 perusahaan yang mengalami overpricing dan 3 perusahaan yang tidak mengalami perubahan harga saham atau tetap. Tingkat underpricing tertinggi terjadi pada tahun 2018 dengan persentase underpricing sebesar $91,23 \%$ dan tingkat underpricing terendah terjadi pada tahun 2015 dengan persentase underpricing sebesar 55,56\%. Hal ini menunjukkan bahwa sebagian besar perusahaan yang melakukan IPO pada periode tersebut mengalami fenomena underpricing.

Bagi perusahaan, kondisi underpricing tentunya tidak menguntungkan karena jumlah dana yang diperoleh pada saat penawaran saham perdana menjadi tidak maksimum. Kondisi underpricing justru menguntungkan investor karena akan memperoleh initial return (return awal) yaitu keuntungan yang diterima karena adanya selisih harga saham yang dibeli di pasar perdana dengan harga jual saham di pasar sekunder, sehingga investor cenderung lebih tertarik pada saham yang mengalami underpricing.

Faktor yang mempengaruhi underpricing bisa dilihat dari faktor keuangan dan non keuangan. Faktor keuangan seperti kinerja keuangan untuk menilai kondisi keuangan perusahaan. Kinerja keuangan dapat diukur dengan rasio solvabilitas, profitabilitas, aktivitas, likuiditas, dan ukuran pasar. Beberapa penelitian mengenai underpricing beberapa dekade ini memusatkan kepada beberapa pengukuran rasio solvabilitas, rasio profitabilitas danukuran perusahaan (Partama dan Gayatri, 2019; Saputra dan Suaryana, 2016).

Penelitian mengenai faktor-faktor (seperti rasio solvabilitas, rasio profitabilitas dan ukuran perusahaan) yang mempengaruhi tingkat underpricing pada perusahaan yang melakukan 
IPO telah banyak dilakukan dan masih ditemukan adanya inkonsistensi hasil penelitian. Salah satu ukuran rasio solvabilitas yaitu Debt to Equity Rasio (DER) dinyatakan memiliki pengaruh positif terhadap tingkat underpricing pada perusahaan yang melakukan IPO (Saputra dan Suaryana, 2016; Widhiastina dan Prihatni, 2016). Ukuran DER ini bisa juga mepengaruhi secara negatif pada tingkat underpricing (Imawati dan Adnyana, 2017) Beberapa penelitian mengungkapkan hasil pengaruh yang tidak signifikan yaitu, DER yang merupakan pengukuran kemampuan perusahaan membayar hutangnya berdasar modal yang dimiliki tidak mempengaruhi tingkat underpricing perusahaan (Ayuwardani dan Isroah, 2018; Djashan, 2017; Partama dan Gayatri, 2019). Maka dari itu penelitian ini menambah dukungan pada literatur rasio solvabilitas dalam mempengaruhi tingkat underpricing.

Beberapa penelitian mengenai rasio profitabilitas yang sering diukur dengan Return on Asset (ROA) dan Return on Equity (ROE) mengungkapkan hasil yang berbeda-beda. ROA yang merupakan kemampuan perusahaan menghasilkan laba berdasar aset yang dimiliki akan mempengaruhi tingkat underpricing dengan arah yang negatif (Imawati dan Adnyana, 2017; Saputra dan Suaryana, 2016). Penelitian lain membuktikan sebaliknya yaitu ROA berpengaruh positif signifikan terhadap tingkat underpricing (Widhiastina dan Prihatni, 2016). Berbeda pula dengan hasil dari kajian lainnya yang mengungkapkan bahwa ROA tidak signifikan memiliki pengaruh terhadap tingkat underpricing (Nuryasinta dan Haryanto, 2017; Permatasari dan Kusumah, 2017).

Begitu pula kajian mengenai ROE memperlihatkan hasil yang tidak konsisten. ROE dinyatakan memiliki pengaruh yang negatif signifikan terhadap tingkat underpricing (Partama dan Gayatri, 2019; Sembiring dkk., 2018). Kemampuan perusahaan dalam menghasilkan laba dengan penggunaan ekuitas yang dimilikinya (ROE) di nyatakan berpengaruh positif sgnifikan terhadap tingkat underpricing (Ayuwardhani dan Isroah, 2018). Hasil penelitian lain menemukan bahwa ROE tidak signifikan dalam mempengaruhi tingkat underpricing (Djashan, 2017; Saputro dkk., 2018). Maka dari itu penelitian ini mencoba menutup kesenjangan dengan menambah dukungan literatur pada rasio profitabilitas yaitu ROA dan ROE pada tingkat underpricing.

Penelitian ini juga memberikan kontribusi kepada tingkat underpricing yang dihubungkan dengan ukuran perusahaan. Yang mana kajian penelitian terdahulu masih belum mendapatkan kesepakatan. Beberapa penelitian mengungkapkan hasil ukuran perusahaan memberikan pengaruh negatif signifikan kepada tingkat underpricing (Partama dan Gayatri, 2019; Saputra dan Suaryana, 2016; Widhiastina dan Prihatni, 2016). Beberapa penelitian terdahulu yang lain mengungkapkan hasil dengan arah yang berbeda, yaitu ukuran perusahaan positif berhubungan dengan underpricing (Nuryasinta dan Haryanto, 2017; Sembiring dkk., 2018). Lain halnya dengan Djashan (2017) dalam penelitiannya pada perusahaan yang melakukan IPO di tahun 2009-2012 menunjukkan bahwa variabel ukuran perusahaan terbukti tidak berpengaruh signifikan terhadap terjadinya underpricing.

Ketidakkonsistenan hasil penelitian terdahulu menjadi landasan utama tujuan penelitian ini. Penelitian ini bertujuan untuk menguji faktor-faktor yang mempengaruhi tingkat underpricing dilihat dari DER, ROA, ROE dan ukuran perusahaan. Penelitian ini memberikan kontribusi dengan memberikan dukungan literatur dan menutup kesenjangan pada faktor-faktor yang mempengaruhi tingkat underpricing.

\section{KAJIAN PUSTAKA}

\section{Tingkat Underpricing}

Saham perusahan yang go public akan ditawarkan terlebih dahulu kepada publik di pasar perdana untuk pertama kalinya atau dikenal dengan Initial Public Offering (IPO). Setelah penjualan saham di pasar perdana, saham perusahaan dapat diperjualbelikan di pasar sekunder. Penentuan harga 
saham di pasar perdana berdasarkan kesepatakan antara perusahaan (emiten) dengan penjamin emisi (underwriter), sedangkan pada pasar sekunder, penentuan harga sahamnya berdasarkan mekanisme pasar melalui permintaan dan penawaran di pasar modal. Tidak mudah untuk menetapkan harga saham perdana di suatu perusahaan karena terbatasnya informasi mengenai harga yang relevan sehingga tidak ada acuan yang dapat diamati untuk menentukan harga saham yang wajar.

Perbedaan kepentingan juga menjadi penyebab sulitnya menetapkan harga saham perdana. Emiten umumnya menetapkan harga penawaran saham yang cukup tinggi agar mendapatkan pemasukan yang maksimal guna memenuhi kebutuhan perusahaan dan menutupi biaya-biaya yang dikeluarkan saat penawaran umum perdana, sedangkan underwriter ingin menetapkan harga penawaran yang rendah untuk menarik minat investor sehingga seluruh saham dapat terjual dan penjamin emisi tidak perlu menanggung kerugian dengan membeli saham yang tidak laku terjual sebagi bentuk tanggung jawab penjaminannya (Syafira dan Kamal, 2016).

Kondisi ketika harga saham pada saat IPO lebih rendah dibandingkan harga penutupan saham pada hari pertama di pasar sekunder disebut dengan underpricing. Sebaliknya, kondisi ketika harga saham pada saat IPO lebih tinggi dibandingkan harga penutupan saham pada hari pertama di pasar sekunder disebut dengan overpricing.

Underpricing dapat terjadi karena adanya asimetri informasi, baik antara emiten dengan penjamin emisi maupun antar kelompok investor. Asimetri informasi merupakan kondisi ketidakseimbangan informasi yang terjadi ketika salah satu pihak memiliki informasi yang lebih banyak dibandingkan yang lainnya. Underwriter memiliki informasi yang lebih rinci mengenai permintaan pasar yang potensial dibandingkan emiten. Asimetri informasi yang terjadi pada kelompok investor yaitu ketika sebagian investor memiliki informasi (informed investors) yang lebih besar dibandingkan sebagian investor yang tidak memiliki informasi (uninformed investors), informasi ini berkaitan dengan kondisi dan prospek perusahaan di masa mendatang sehingga mempengaruhi keputusan investor dalam membeli saham. Informed investors akan memilih untuk membeli saham perusahaan yang mengalami underpriced, sedangkan uniformed investor akan membeli saham perusahaan tanpa memperhatikan saham tersebut mengalami underpriced atau overpriced karena terbatasnya informasi yang dimiliki.

Untuk meminimalisir terjadinya underpricing yang disebabkan oleh asimetri informasi, perlu dilakukan penerbitan prospektus. Prospektus perusahaan merupakan salah satu sumber informasi yang relevan dan dapat digunakan untuk menilai perusahaan yang akan go public dan untuk mengurangi adanya kesenjangan informasi (Permadi dan Yasa, 2017). Investor dapat menilai kinerja suatu perusahaan dengan menggunakan informasi keuangan dan non keuangan yang terdapat di dalam prospektus. Dengan adanya prospektus, diharapkan dapat membantu investor dalam membuat keputusan investasi yang rasional.

Kinerja keuangan merupakan suatu analisis yang dilakukan untuk melihat sejauh mana suatu perusahaan telah melaksanakan dengan menggunakan aturan-aturan pelaksanaan keuangan secara baik dan benar (Fahmi, 2015). Kinerja keuangan dapat diukur dengan menggunakan rasio keuangan. Rasio keuangan yang umum digunakan dalam menilai kondisi keuangan perusahaan adalah rasio likuiditas, rasio solvabilitas, rasio aktivitas, rasio profitabilitas, dan rasio penilaian atau rasio ukuran pasar.

\section{Debt to Equity Ratio (DER) dan Tingkat Underpricing}

Debt to Equity Ratio (DER) merupakan salah satu rasio solvabilitas yang mengukur kapabilitas perusahaan dalam membayar hutangnya menggunakan modal yang dimilikinya. Semakin tinggi DER mengindikasikan risiko yang ditanggung perusahaan juga tinggi. Hal ini akan berdampak 
terhadap ketidakpastian harga saham yang semakin besar, sehingga tingkat underpricing yang dialami perusahaan akan semakin tinggi.

Saputra dan Suaryana (2016) melakukan penelitian pada perusahaan yang melakukan IPO di BEI tahun 2010-2013 menunjukkan bahwa financial leverage yang diukur dengan DER berpengaruh positif pada underpricing. Widhiastina dan Prihatni (2016) dalam penelitiannya pada perusahaan yang melakukan IPO di BEI tahun 2010-2013 menunjukkan hasil yang sama yaitu debt to equity ratio berpengaruh signifikan dan hubungan positif dengan underpricing. Maka dari itu hipotesis yang diajukan adalah:

H1 : Debt to Equity Ratio (DER) berpengaruh positif terhadap tingkat underpricing.

\section{Return on Asset (ROA) dan Tingkat Underpricing}

Return on Asset (ROA) merupakan salah satu rasio profitabilitas yang mengukur kapabilitas perusahaan dalam menghasilkan laba menggunakan aset yang dimilikinya. Semakin tinggi ROA mengindikasikan tingginya kemampuan perusahaan dalam menghasilkan laba di masa yang akan datang. Hal ini akan mengurangi tingkat ketidakpastian, sehingga akan mengurangi tingkat underpricing.

Saputra dan Suaryana (2016) melakukan penelitian pada perusahaan yang melakukan IPO di BEI tahun 2010-2013 menunjukkan bahwa return on assets berpengaruh negatif pada underpricing. Sama halnya dengan Imawati dan Adnyana (2017) yang meneliti faktor-faktor mikro dan makroekonomi terhadap tingkat underpricing berdasarkan data tahun 2011-2015 menunjukkan bahwa ROA berpengaruh negatif dan signifikan terhadap tingkat underpricing. Hipotesis penelitian yang diajukan adalah:

$\mathrm{H} 2$ : Return on Asset (ROA) berpengaruh negatif terhadap tingkat underpricing.

\section{Return on Equity (ROE) dan Tingkat Underpricing}

Return on Equity (ROE) merupakan salah satu rasio profitabilitas yang mengukur kapabilitas perusahaan dalam menghasilkan laba untuk para pemegang saham dengan menggunakan ekuitas yang dimilikinya. Semakin tinggi ROE mengindikasikan tingginya kemampuan perusahaan dalam menghasilkan labanya. Hal ini akan mengurangi tingkat ketidakpastian harga saham, sehingga akan mengurangi tingkat underpricing.

Sembiring, dkk. (2018) meneliti faktor yang mempengaruhi underpricing pada perusahaan yang melakukan IPO tahun 2010-2016 menunjukkan bahwa secara parsial variabel return on equity berpengaruh negatif dan signifikan terhadap underpricing. Partama dan Gayatri (2019) dalam penelitiannya pada perusahaan yang melakukan IPO di tahun 2013-2017 menunjukkan bahwa variabel return on equity berpengaruh negatif signifikan terhadap underpricing.

H3: Return on Equity (ROE) berpengaruh negatif terhadap tingkat underpricing.

\section{Ukuran Perusahaan dan Tingkat Underpricing}

Ukuran perusahaan merupakan besar kecilnya ukuran perusahaan berdasarkan total asset yang dimilikinya. Informasi mengenai perusahaan lebih banyak dan lebih mudah diperoleh investor dibandingkan perusahaan kecil, hal ini akan mengurangi tingkat underpricing (Saputra dan Suaryana, 2016).

Saputra dan Suaryana (2016) melakukan penelitian pada perusahaan yang melakukan IPO di BEI tahun 2010-2013 menunjukkan bahwa ukuran perusahaan berpengaruh negatif pada underpricing. Widhiastina dan Prihatni (2016) dalam penelitiannya pada perusahaan yang melakukan IPO di BEI tahun 2010-2013 menunjukkan bahwa ukuran perusahaan berpengaruh signifikan dan hubungan negatif dengan underpricing. Imawati dan Adnyana (2017) yang meneliti faktor-faktor mikro dan makroekonomi terhadap tingkat underpricing berdasarkan data tahun 
2011-2015 juga menunjukkan hasil yang sama yaitu ukuran perusahaan berpengaruh negatif dan signifikan terhadap tingkat underpricing. Permatasari dan Kusumah (2017) dalam penelitiannya pada perusahaan yang melakukan IPO di BEI tahun 2008-2015 menunjukkan bahwa ukuran perusahaan secara parsial berpengaruh negatif dan signifikan terhadap tingkat underpricing. Sama halnya dengan Partama dan Gayatri (2019) dalam penelitiannya pada perusahaan yang melakukan IPO di tahun 2013-2017 menunjukkan bahwa variabel ukuran perusahaan berpengaruh negatif signifikan terhadap underpricing.

H4: Ukuran perusahaan berpengaruh negatif terhadap tingkat underpricing.

\section{METODE}

\section{Populasi dan Sampel}

Objek dalam penelitian ini adalah tingkat underpricing yang dipengaruhi oleh debt to equity ratio (DER), return on asset (ROA), return on equity (ROE) dan ukuran perusahaan. Subjek dalam penelitian ini adalah perusahaan yang melakukan Initial Public Offering (IPO) di Bursa Efek Indonesia selama periode 2014-2019. Jenis penelitian yang digunakan adalah penelitian deskriptif. Populasi yang digunakan dalam penelitian ini adalah seluruh perusahaan yang melakukan initial public offering (IPO) di Bursa Efek Indonesia (BEI) selama periode 2014-2019. Selama periode tersebut, diperoleh sebanyak 207 perusahaan yang menjadi populasi dalam penelitian ini. Penentuan sampel dilakukan dengan menggunakan metode purposive sampling yaitu teknik penentuan sampel dengan kriteria tertentu sehingga dapat diperoleh sampel yang sesuai dengan tujuan dan masalah penelitian yang dikembangkan. Adapun penentuan sampel pada penelitian ini dilakukan berdasarkan kriteria dan perhitungan yang dapat dilihat pada tabel 2 .

\section{Tabel 2. Pengambilan Sampel}

\begin{tabular}{lc}
\multicolumn{1}{c}{ Kriteria } & Jumlah \\
\hline Perusahaan yang melakukan IPO periode 2014-2019 & 207 \\
Perusahaan tidak mengalami underpricing & $(41)$ \\
Perusahaan bergerak dalam sektor keuangan & $(14)$ \\
Perusahaan yang relisting & $(4)$ \\
Laporan keuangan perusahaan menggunakan mata uang selain rupiah & $(8)$ \\
Data perusahaan menunjukkan perusahaan mengalami kerugian & $(25)$ \\
\hline Jumlah perusahaan yang memenuhi kriteria sampel & 115 \\
\hline
\end{tabular}

Sumber data diolah

\section{Metode Pengukuran Data}

Tingkat Underpricing (Y): Selisih antara harga saham penutupan hari pertama di pasar sekunder dengan harga saham penawaran di pasar perdana.

$\mathrm{IR}=\frac{\mathrm{CP}-\mathrm{OP}}{\mathrm{OP}} \times 100 \%$

Keterangan:

IR = Initial Return

$\mathrm{CP}=$ Closing Price

$\mathrm{OP}=$ Offering Price

Sumber: Tandelilin (2001) dalam Widhiastina dan Prihatni (2016)

Debt to Equity Ratio (DER) (X1): Rasio yang menunjukkan kapabilitas perusahaan dalam membayar hutangnya menggunakan modal yang dimilikinya.

DER $=\frac{\text { Total Hutang }}{\text { Total Ekuitas }}$

Sumber: Widyatuti (2017) 
Return on Asset (ROA) (X2): Rasio yang menunjukkan kapabilitas perusahaan dalam menghasilkan laba menggunakan aset yang dimiliki.

ROA $=\frac{\text { Laba Bersih }}{\text { Total Aset }}$

Sumber: Hery (2015)

Return on Equity (ROE) (X3): Rasio yang menunjukkan kapabilitas perusahaan dalam menghasilkan laba dengan menggunakan ekuitas yang dimilikinya.

ROE $=\frac{\text { Laba Bersih }}{\text { Total Ekuitas }}$

Sumber: Hery (2015)

Ukuran Perusahan (X4): Besar kecilnya ukuran perusahaan berdasarkan total aktiva yang dimilikinya.

Size = Ln Total Aktiva

Sumber: Saputra dan Suaryana (2016)

\section{Metode Analisis}

Hipotesis penelitian diuji dengan menggunakan regresi berganda. Pengujian regresi berganda dilakukan dengan dibantu alat SPSS 23. Sebelum pengujian regresi berganda, dilakukan uji asumsi antara lain uji normalitas, heterokedastisitas, multikolinieritas dan juga autokorelasi.

Persamaan regresi berganda dalam penelitian ini dapat dituliskan sebagai berikut.

$Y=\alpha_{0}+\alpha_{1} X_{1}+\alpha_{2} X_{2}+\alpha_{3} X_{3}+\alpha_{4} X_{4}+e$

Keterangan:

$\mathrm{Y} \quad=$ Tingkat Underpricing

$\alpha_{0} \quad=$ Konstanta

$\mathrm{X}_{1} \quad=$ Debt to Equity Ratio

$\mathrm{X}_{2} \quad=$ Return on Asset

$\mathrm{X}_{3} \quad=$ Return on Equity

$\mathrm{X}_{4} \quad=$ Ukuran Perusahaan

$\alpha_{1,2,3,4}=$ Koefisien variabel dependen

e $\quad$ Standard Error

\section{HASIL DAN PEMBAHASAN}

\section{Analisa Deskriptif}

Tabel 3 memperlihatkan hasil rata-rata dan standar deviasi setiap variabel. Nilai rata-rata yang lebih besar daripada standar deviasi menunjukkan bahwa data bersifat homogen dan ketika nilai rata-rata lebih kecil dibandingkan nilai standar deviasi maka data bersifat heterogen.

Tabel 3. Hasil Uji Deskriptif, Mean, SD

\begin{tabular}{lcc}
\hline VAR & Mean & Std Deviation \\
\hline UND &, 588 &, 372 \\
DER & 2,387 & 6,207 \\
ROA &, 088 &, 101 \\
ROE &, 213 &, 266 \\
SIZE & 26,739 & 1,478 \\
\hline
\end{tabular}

Sumber data diolah

Tingkat underpricing dan ukuran perusahaan menunjukkan hasil data bersifat homogen, ditunjukkan dari nilai standar deviasinya lebih kecil dibandingkan dengan nilai rata-ratanya. Hal ini menunjukkan rata-rata tingkat underpricing dan ukuran perusahaan memiliki tingkat penyimpangan yang rendah. Sedangkan pada variabel DER, ROA, dan ROE nilai standar deviasi 
lebih besar daripada nilai rata-ratanya, sehingga dapat dikatakan data bersifat heterogen, dikarenakan sebaran data bervariasi, yang berarti rata-rata DER, ROA, dan ROE memiliki tingkat penyimpangan yang tinggi.

\section{Uji Hipotesis}

Uji asumsi dilaksanakan sebelum melakukan uji hipotesis dengan regresi berganda melalui SPSS 23. Hal ini digunakan untuk terpenuhinya syarat pengujian bagi uji regresi berganda yang menggunakan SPSS, untuk memastikan bahwa hasil bisa diinterpretasikan dengan semestinya. Uji asumsi yang digunakan adalah uji normalitas, uji heterokedastisitas, uji multikolinieritas dan uji autokorelasi.

Uji normalitas dalam penelitian ini mempergunakan metode kolmogorov smirnov, dan didapatkan hasil nilai Asymp.sig . (2-tailed) nya sebesar 0,087. Hal ini menjelaskan bahwa data residual berdistribusi secara normal dan asumsi normalitas terpenuhi. Uji autokorelasi menunjukkan nilai Durbin Watson (DW) sebesar 1,933. Nilai tersebut akan dibandingkan dengan nilai tabel Durbin Watson dengan signifikansi 5\%, jumlah sampel $(\mathrm{N})=115$ dan jumlah variabel independen $(K)=4$ diperoleh nilai $d U=1,7683$. Nilai DW sebesar 1,933 terletak di antara dU yang bernilai 1,7683 dan $4-\mathrm{dU}$ yang bernilai 2,2317 atau 1,7683 $<1,933<2,2317$, maka dapat disimpulkan tidak terdapat autokorelasi di dalam model regresi yang digunakan.

Tabel 4. Hasil Uji multikolinieritas dan Heterokedastisitas

\begin{tabular}{lllll}
\hline \multirow{2}{*}{ VAR } & \multicolumn{2}{c}{ Collinearity Statistic } & \multicolumn{2}{c}{ Heterokedastisitas } \\
\cline { 2 - 5 } & TOLERANCE & VIF & T & Sig \\
\hline DER &, 627 & 1,595 &, 195 &, 846 \\
ROA &, 559 & 1,789 & 1,021 &, 309 \\
ROE &, 460 & 2,173 &,- 636 &, 526 \\
SIZE &, 989 & 1,012 &, 121 &, 904 \\
\hline
\end{tabular}

Sumber data diolah

Tabel 4 menunjukkan hasil pengujian multikolinieritas dan uji heterokedastisitas. Uji heteroskedastisitas menggunakan uji Glejser menunjukkan bahwa setiap variabel independen memiliki nilai signifikansi $>0,05$, maka dapat disimpulkan tidak terjadi heteroskedastisitas pada model regresi. uji multikolinieritas menunjukkan bahwa variabel independen DER, ROA, ROE, dan SIZE memiliki nilai tolerance $>0,1$ dan nilai VIF $<10$, maka dapat disimpulkan tidak terdapat multikolinieritas antar variabel independen di dalam model regresi.

\section{Pengujian Hipotesis}

Pengujian Hipotesis dengan regresi berganda dapat dilihat pada tabel 5.

Tabel 5. Hasil Pengujian Regresi Berganda

\begin{tabular}{|c|c|c|c|c|c|}
\hline Variabel & Unstd Beta & Std Beta & $\mathrm{t}$ & Sig & Keterangan \\
\hline constant & 2,907 & ,574 & 5,068 & ,000 & \\
\hline DER & 001 & ,006 & ,056 & 955 & ditolak \\
\hline ROA &,- 861 &,- 233 & $-2,064$ & 041 & diterima \\
\hline ROE & -188 &,- 134 & $-1,078$ & ,284 & ditolak \\
\hline SIZE &,- 082 &,- 328 & $-3,857$ & ,000 & diterima \\
\hline Adj $R^{2}$ & & & 0,186 & & \\
\hline F & & & 7,491 & 0,000 & \\
\hline
\end{tabular}

Sumber data diolah 
Persamaan regresi berganda dalam penelitian ini dengan melihat hasil dari tabel 5 adalah sebagai berikut:

\section{UND = 2,907 + 0,001DER - 0,861ROA - 0,188ROE - 0,082SIZE}

Dari persamaan regresi tersebut dapat dijelaskan bahwa nilai konstanta yang diperoleh sebesar 2,907. Hal ini mengindikasikan jika semua variabel independen dianggap konstan (bernilai 0), maka besarnya tingkat underpricing sebesar 2,907. Nilai koefisien regresi debt to equity ratio (DER) sebesar 0,001 , bernilai positif artinya terdapat hubungan searah dengan tingkat underpricing. Hal ini menunjukkan bahwa apabila debt to equity ratio ditingkatkan sebesar satu satuan maka tingkat underpricing juga akan meningkat sebesar 0,001 dengan asumsi variabel independen lainnya konstan. Nilai koefisien regresi return on asset (ROA) sebesar 0,861 , bernilai negatif artinya terdapat hubungan yang berbanding terbalik dengan tingkat underpricing. Hal ini mengindikasikan bahwa peningkatan yang terjadi pada return on asset sebesar satu satuan akan diikuti dengan penurunan tingkat underpricing sebesar 0,861 dengan asumsi variabel independen lainnya konstan. Nilai koefisien regresi return on equity (ROE) sebesar - 0,188, bernilai negatif artinya terdapat hubungan yang berbanding terbalik dengan tingkat underpricing. Ketika return on equity terjadi peningkatan sebesar satu satuan akan disertai penurunan tingkat underpricing sebesar 0,188 dengan asumsi variabel independen lainnya konstan. Nilai koefisien regresi ukuran perusahaan (SIZE) sebesar - 0,082, bernilai negatif artinya terdapat hubungan yang berbanding terbalik dengan tingkat underpricing. Hal ini menunjukkan bahwa setiap peningkatan pada ukuran perusahaan sebesar satu satuan akan disertai penurunan tingkat underpricing sebesar 0,082 dengan asumsi variabel independen lainnya konstan.

Berdasarkan tabel 5 diperoleh nilai F hitung sebesar 7,491 dan nilai signifikansi 0,000< 0,05 , maka dapat disimpulkan model regresi yang digunakan dalam menguji pengaruh antara variabel independen terhadap variabel dependen dikatakan layak (fit) untuk digunakan dalam penelitian. Berdasarkan tabel 5, dapat diketahui bahwa nilai Adjusted $R$ Square sebesar 0,186 atau $18,6 \%$. Hal ini menunjukkan bahwa variabel DER, ROA, ROE, dan ukuran perusahaan memberikan kontribusi dalam menjelaskan tingkat underpricing sebesar $18,6 \%$, sedangkan sisanya $81,4 \%$ dijelaskan oleh variabel lain yang tidak diamati dalam penelitian ini.

Berdasarkan tabel 5, hasil uji t menunjukkan bahwa variabel debt to equity ratio (DER)

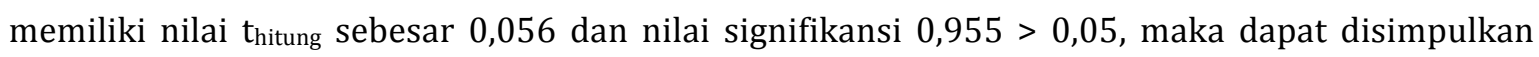
bahwa variabel DER berpengaruh positif dan tidak signifikan terhadap tingkat underpricing secara parsial. Dengan demikian hipotesis yang menyatakan bahwa debt to equity ratio (DER) berpengaruh positif dan signifikan terhadap tingkat underpricing tidak terbukti $\left(\mathrm{H}_{0}\right.$ diterima dan $\mathrm{H}_{1}$ ditolak). Hipotesis 1 ditolak. Hasil uji t menunjukkan bahwa variabel return on asset (ROA) memiliki nilai thitung sebesar $-2,064$ dan nilai signifikansi 0,041<0,05, maka hipotesis 2 diterima. hipotesis yang menyatakan bahwa return on asset (ROA) berpengaruh negatif dan signifikan terhadap tingkat underpricing terbukti.

Hipotesis 3 tidak diterima atau ditolak dengan menunjuk hasil uji $t$ pada tabel 5 , menunjukkan bahwa variabel return on equity (ROE) memiliki nilai thitung sebesar -1,078 dan nilai signifikansi 0,284 >0,05, maka dapat disimpulkan bahwa variabel ROE berpengaruh negatif dan tidak signifikan terhadap tingkat underpricing secara parsial. Dengan demikian hipotesis yang menyatakan bahwa return on equity (ROE) berpengaruh negatif dan signifikan terhadap tingkat underpricing tidak terbukti. Hipotesis 4 diterima, ditunjukkan dari variabel ukuran perusahaan

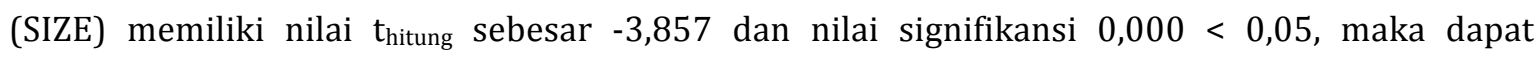
disimpulkan bahwa variabel SIZE berpengaruh negatif dan signifikan terhadap tingkat underpricing. Dengan demikian hipotesis yang menyatakan bahwa ukuran perusahaan (SIZE) berpengaruh negatif dan signifikan terhadap tingkat underpricing. 


\section{Pengaruh Debt to Equity Ratio terhadap Tingkat Underpricing}

Hasil penelitian menunjukkan bahwa debt to equity ratio (DER) berpengaruh positif dan tidak signifikan terhadap tingkat underpricing. Hasil penelitian ini sejalan dengan hasil penelitian yang dilakukan oleh Djashan (2017), Nuryasinta dan Haryanto (2017), Ayuwardani dan Isroah (2018) serta Partama dan Gayatri (2019) yang menyatakan bahwa debt to equity ratio tidak berpengaruh terhadap tingkat underpricing. Hasil ini mencerminkan bahwa perusahaan yang memiliki tingkat DER yang tinggi belum tentu mengalami tingkat underpricing yang tinggi. Sebaliknya, perusahaan yang memiliki tingkat DER yang rendah belum tentu mengalami tingkat underpricing yang rendah. Hal ini didukung dengan kondisi empiris dari PT. Jasa Armada Indonesia Tbk (IPCM) yang melakukan penawaran perdana ditahun 2017 memiliki DER sebesar 0,7770 atau 77,7\% mengalami tingkat underpricing sebesar 0,0579 atau 5,79\%. Sementara itu, PT. Terregra Asia Energy Tbk (TGRA) yang melakukan penawaran perdana ditahun yang sama memiliki DER yang lebih rendah yaitu 0,1002 atau $10,02 \%$ justru mengalami tingkat underpricing yang cukup tinggi yaitu 0,7000 atau $70 \%$.

Hasil penelitian ini tidak mendukung teori signalling yang menyatakan tingkat DER yang tinggi pada suatu perusahaan merupakan sinyal buruk bagi investor karena mengindikasikan tingginya ketidakpastian perusahaan dimasa mendatang. Hal ini disebabkan tingkat DER yang tinggi tidak selalu mengindikasikan rendahnya kemampuan perusahaan dalam memenuhi kewajibannya. Jika dikaitkan dengan informasi yang disajikan di dalam prospektus, perusahaan akan menggunakan sebagian dana yang diperoleh dari IPO untuk melunasi kewajibannya, sehingga dimasa depan perusahaan tidak akan terbebani dengan kewajiban yang tinggi dan kinerjanya akan jauh lebih baik yang akan berdampak pada kenaikan harga saham perusahaan di masa depan (Utomo dan Kurniasih, 2020).

Meskipun DER tidak memberikan kontribusi dalam mempengaruhi tingkat underpricing, perusahaan tetap harus berupaya agar nilai DER yang dimiliki tidak terlalu tinggi. Hal ini bertujuan agar ketergantungan perusahaan terhadap hutang tidak terlalu besar, sehingga perusahaan dapat menghindari risiko gagal bayar yang mungkin terjadi.

\section{Pengaruh Return on Asset terhadap Tingkat Underpricing}

Hasil penelitian menunjukkan bahwa return on asset (ROA) berpengaruh negatif dan signifikan terhadap tingkat underpricing. Hasil penelitian ini sejalan dengan hasil penelitian yang dilakukan oleh Saputra dan Suaryana (2016) serta Imawati dan Adnyana (2017) yang menyatakan bahwa return on asset berpengaruh negatif dan signifikan terhadap tingkat underpricing. Hasil ini mencerminkan bahwa semakin tinggi tingkat ROA yang dimiliki perusahaan maka semakin rendah tingkat underpricing yang dialami perusahaan. Sebaliknya, semakin rendah tingkat ROA yang dimiliki perusahaan maka semakin tinggi tingkat underpricing yang dialami perusahaan.

Hasil penelitian ini mendukung teori signalling yang menyatakan tingkat ROA yang tinggi merupakan sinyal yang baik bagi investor karena mengindikasikan rendahnya ketidakpastian perusahaan dimasa mendatang sehingga akan menarik minat investor untuk membeli saham. Hal ini akan mengakibatkan harga penawaran saham pada saat IPO semakin tinggi. Tingginya harga penawaran saham pada saat IPO akan mengurangi tingkat underpricing yang dialami perusahaan.

Perusahaan yang memiliki tingkat ROA yang tinggi sebaiknya dapat memanfaatkan kesempatan ini untuk menetapkan harga penawaran saham yang tinggi pada saat IPO sehingga perusahaan dapat meminimalisir terjadinya underpricing. Hal ini dikarenakan investor menganggap perusahaan memiliki prospek yang baik dimasa yang akan datang sehingga investor akan tertarik untuk membeli saham bahkan jika harga saham tersebut ditetapkan diharga yang tinggi. 


\section{Pengaruh Return on Equity terhadap Tingkat Underpricing}

Hasil penelitian menunjukkan bahwa return on equity (ROE) berpengaruh negatif dan tidak signifikan terhadap tingkat underpricing. Hasil penelitian ini sejalan dengan hasil penelitian yang dilakukan oleh Djashan (2017) dan Saputro, dkk. (2018) yang menyatakan bahwa return on equity tidak berpengaruh terhadap tingkat underpricing. Hasil ini mencerminkan bahwa perusahaan yang memiliki tingkat ROE yang tinggi belum tentu mengalami tingkat underpricing yang rendah. Sebaliknya, perusahaan yang memiliki tingkat ROE yang rendah belum tentu mengalami tingkat underpricing yang tinggi. Hal ini didukung dengan kondisi empiris dari PT. MAP Boga Adiperkasa Tbk (MAPB) yang melakukan penawaran perdana ditahun 2017 memiliki ROE sebesar 0,7853 atau $78,3 \%$ dengan tingkat underpricing sebesar 0,5000 atau 50\%. Sementara itu, PT. Integra Indocabinet Tbk (WOOD) yang melakukan penawaran perdana ditahun yang sama memiliki ROE yang lebih kecil yaitu 0,0987 atau 9,87\% justru mengalami tingkat underpricing yang cukup rendah yaitu 0,0154 atau $1,54 \%$.

Hasil ini tidak mendukung teori signalling yang menyatakan tingkat ROE yang tinggi merupakan sinyal baik bagi investor karena mengindikasikan rendahnya ketidakpastian perusahaan dimasa mendatang. Hal ini disebabkan informasi mengenai return on equity (ROE) yang disajikan emiten melalui penerbitan prospektus tidak menjadi salah satu bahan pertimbangan bagi investor dalam mengambil keputusan investasinya.

Meskipun ROE tidak memberikan kontribusi dalam mempengaruhi tingkat underpricing, perusahaan tetap harus berupaya untuk meningkatkan nilai ROE yang dimiliki. Hal ini bertujuan agar pemanfaatan ekuitas yang dimiliki perusahaan semakin efisien, sehingga diharapkan dapat menghasilkan laba bersih dari pemanfaatan ekuitas tersebut.

\section{Pengaruh Ukuran Perusahaan terhadap Tingkat Underpricing}

Hasil penelitian menunjukkan bahwa ukuran perusahaan berpengaruh negatif dan signifikan terhadap tingkat underpricing. Hasil penelitian ini sejalan dengan hasil penelitian yang dilakukan oleh Saputra dan Suaryana (2016), Widhiastina dan Prihatni (2016), Imawati dan Adnyana (2017), Permatasari dan Kusumah (2017) serta Partama dan Gayatri (2019) yang menyatakan bahwa ukuran perusahaan berpengaruh negatif dan signifikan terhadap tingkat underpricing. Hasil ini mencerminkan bahwa semakin besar total aset yang dimiliki perusahaan maka semakin rendah tingkat underpricing yang dialami perusahaan. Sebaliknya, semakin kecil total aset yang dimiliki perusahaan maka semakin tinggi tingkat underpricing yang dialami perusahaan.

Semakin besar ukuran perusahaan, maka semakin banyak dan semakin mudah informasi yang didapatkan oleh investor. Hal ini dapat mengurangi ketidakpastian terhadap nilai perusahaan karena investor dapat mengetahui prospek perusahaan dimasa yang akan datang sehingga akan menarik minat investor untuk membeli saham. Hal ini akan mengakibatkan harga penawaran saham pada saat IPO semakin tinggi. Tingginya harga penawaran saham pada saat IPO akan mengurangi tingkat underpricing yang dialami perusahaan.

Perusahaan yang memiliki aktiva yang besar sebaiknya dapat memanfaatkan kesempatan ini untuk menetapkan harga penawaran saham yang tinggi pada saat IPO sehingga perusahaan dapat meminimalisir terjadinya underpricing. Hal ini dikarenakan investor menganggap perusahaan memiliki prospek yang baik dimasa yang akan datang sehingga investor akan tertarik untuk membeli saham bahkan jika harga saham tersebut ditetapkan diharga yang tinggi.

\section{KESIMPULAN DAN IMPLIKASI}

Penelitian ini bertujuan untuk mengetahui pengaruh debt to equity ratio, return on asset, return on equity dan ukuran perusahaan terhadap tingkat underpricing pada perusahaan yang melakukan initial public offering (IPO) di BEI periode 2014 - 2019. Kesimpulan yang diambil dari hasil 
penelitian ini adalah DER dan ROE tidak signifikan berpengaruh terhadap tingkat underpricing. Sedangkan ROA dan ukuran perusahaan terkbukti signifikan berpengaruh terhadap tingkat underpricing dengan arah yang negatif atau berkebalikan.

Implikasi bagi perusahaan untuk meminimalkan tingkat underpricing maka perlu memperhatikan ROA dan ukuran perusahaan. Hubungan ROA dan ukuran perusahaan terbukti berpengaruh negatif secara signifikan, hal ini memberikan arah bagi perusahaan bahwa ketika meminimalkan tingkat underpricing maka perlu meningkatkan ROA dan ukuran perusahaan. Ketika ROA dan ukuran perusahaan ditingkatkan maka tingkat underpricing akan mengalami penurunan. Hal ini berarti semakin tinggi return on asset (ROA) yang dimiliki perusahaan maka semakin rendah tingkat underpricing yang dialami perusahaan. Begitu pula sebaliknya, semakin rendah return on asset (ROA) yang dimiliki perusahaan maka semakin tinggi tingkat underpricing yang dialami perusahaan. Semakin besar total aktiva atau ukuran perusahaan maka semakin rendah tingkat underpricing yang dialami perusahaan. Begitu pula sebaliknya, semakin kecil total aktiva yang dimiliki perusahaan maka semakin tinggi tingkat underpricing yang dialami perusahaan.

\section{Keterbatasan dan Saran}

Terdapat sejumlah keterbatasan dalam penelitian ini. Pertama metodologi teknik analisis yang digunakan dengan regresi berganda melalui SPSS yang tidak memungkinkan untuk melakukan pengujian dengan data panel, sehingga penelitian ke depan sebaiknya menggunakan alat statistik lainnya yang memungkinkan untuk melihat hasil regresi dengan data panel. Kedua, Faktor yang mempengaruhi tingkat underpricing masih sangat banyak selain dari variabel yang diteliti dalam penelitian ini. Oleh karena itu penelitian ke depan sebaiknya menggali lebih dalam variabelvariabel lain yang menjadi faktor penyebab naik turunnya tingkat underpricing.

\section{REFERENSI}

Abi, F.P.P. 2016. Semakin Dekat dengan Pasar Modal Indonesia. Deepublish. Yogyakarta.

Ayuwardani, R.P. dan Isroah. 2018. Pengaruh Informasi Keuangan dan Non Keuangan Terhadap Underpricing Harga Saham pada Perusahaan yang Melakukan Initial Public Offering (Studi Empiris Perusahaan Go Public yang terdaftar di Bursa Efek Indonesia Tahun 2011-2015). Nominal: Barometer Riset Akuntansi dan Manajemen. 7 (1): 143-158.

Beck, J. 2017. Determinants of IPO Underpricing: Tech vs Non-Tech Industries. Major Themes in Economics. 19 (5): 39-55.

Bursa Efek Indonesia. 2020. https://www.idx.co.id. 29 Oktober 2020 (20:21).

Djashan, I.A. 2017. Analisis Faktor-Faktor Terhadap Underpricing Saham Perdana. Jurnal Bisnis dan Akuntansi. 19 (2): 251-258.

Fahmi, I. 2015. Analisis Laporan Keuangan. Alfabeta. Yogyakarta.

Fauziah, F. 2017. Kesehatan Bank, Kebijakan Dividen dan Nilai Perusahaan: Teori dan Kajian Empiris. Pustaka Horizon. Samarinda.

Ghozali, I. 2011. Aplikasi Analisis Multivariate dengan Program SPSS. Badan Penerbit Universitas Diponegoro. Semarang.

Handini, S. dan E.D. Astawinetu. 2020. Teori Portofolio dan Pasar Modal Indonesia. Scopindo Media Pustaka. Surabaya.

Hantono. 2018. Konsep Analisa Laporan Keuangan dengan Pendekatan Rasio dan SPSS. Deepublish. Yogyakarta.

Hasanudin, A.I. 2018. Teori Akuntansi. Cetta Media. Yogyakarta.

Hery. 2015. Analisis Kinerja Manajemen. Grasindo. Jakarta.

IDN Financials. 2020. https://www.idnfinancials.com. 31 Oktober 2020 (08:14).

Ilham, R.N., K.A. Fachrudin., M. Sinurat., M. Khaddafi. 2020. Manajemen Investasi (Legal Investment Versus Fake Investment). CV Jejak. Sukabumi.

Imawati dan I.M. Adnyana. 2017. Pengaruh Faktor-Faktor Mikro dan Makroekonomi Terhadap 
Tingkat Underpricing Pada Saat Inital Public Offering (IPO). Jurnal Ilmu Manajemen. 13 (2): $72-86$.

Irfani, A.S. 2020. Manajemen Keuangan dan Bisnis: Teori dan Aplikasi. Gramedia Pustaka Utama. Jakarta.

Juliandi, A., Irfan., S. Manurung. 2014. Metodologi Penelitian Bisnis: Konsep dan Aplikasi. Umsu Press. Medan.

Kasmir. 2016. Pengantar Manajemen Keuangan: Edisi Kedua. Preada Media. Jakarta.

Khursed, A. 2011. Initial Public Offerings: The Mechanics and Performance of IPOs. Harriman House. Great Britain.

Martalena dan M. Malinda. 2019. Pengantar Pasar Modal: Didesain untuk Mempelajari Pasar Modal dengan Mudah dan Praktis. Andi. Yogyakarta.

Nurdin, I. dan S. Hartati. 2019. Metodologi Penelitian Sosial. Media Sahabat Cendekia. Surabaya.

Nuryasinta, A. dan M. Haryanto. 2017. Analisis Faktor-Faktor yang Mempengaruhi Initial Return pada Perusahaan Non Keuangan yang Melakukan Initial Public Offering (IPO) di BEI Periode 2010-2015. Diponegoro Journal Of Management. 6 (2): 1-11.

Nuzula, N.F. dan F. Nurlaily. 2020. Dasar-Dasar Manajemen Investasi. UB Press. Malang.

Oktavia, H.C.A. 2019. Analisis Pengaruh Leverage, Profitabilitas, Likuiditas Saham, dan Reputasi Underwriter terhadap Underpricing IPO. Simba: Seminar Inovasi Manajemen, Bisnis dan Akuntansi I. 502-513.

Partama, I.G.N.A. dan Gayatri. 2019. Analisis Determinan Underpricing Saham di Bursa Efek Indonesia. E-Jurnal Akuntansi Universitas Udayana. 26 (3): 2293-2323.

Pemerintah Republik Indonesia. 1995. Undang-Undang No. 8 Tahun 1995 tentang Pasar Modal. Pemerintah Republik Indonesia. Jakarta.

Permadi, P.K.A.R. dan G.W. Yasa. 2017. Reputasi Auditor Sebagai Pemoderasi Pengaruh Informasi Keuangan dalam Prospektus pada Tingkat Underpricing Penawaran Saham Perdana. EJurnal Akuntansi Universitas Udayana. 21 (3): 1963-1992.

Permatasari, R. dan R.W.R. Kusumah. 2017. Pengaruh Return on Asset, Price Earning Ratio, Ukuran Perusahaan, Prosentase Penawaran Saham, dan Reputasi Underwriter Terhadap Tingkat Underpricing (Studi Pada Perusahaan yang Melakukan Initial Public Offering di Bursa Efek Indonesia Periode 2008-2015). Profesionalisme Akuntan Menuju Sustainable Business Practice: SNAB Universitas Widyatama. 261-277.

Purwanti dan E.I. Siregar. 2017. Analisis Faktor yang Mempengaruhi Tingkat Underpricing Perusahaan Manufaktur di Bursa Efek Indonesia Periode 1996-2015. Jurnal Aplikasi Manajemen, Ekonomi dan Bisnis. 2 (1): 73-93.

Saputra, A.C. dan I.G.N. Suaryana. 2016. Pengaruh Umur Perusahaan, Ukuran Perusahaan, Return on Assets dan Financial Leverage pada Underpricing Penawaran Umum Perdana. E-Jurnal Akuntansi Universitas Udayana. 15 (2): 1201-1227.

Saputro, B.E., S.H.E. Friantin., Y. Khristiana. 2018. Pengaruh Underpricing Saham pada Perusahaan yang Melakukan Initial Public Offering. Advance: Journal of Accounting. 5 (1): 8-16.

Sembiring, E.F., G. Rahmawati., F.W. Kusumawati. 2018. Analisis Faktor Yang Mempengaruhi Underpricing Pada Perusahaan Yang Terdaftar di Bursa Efek Indonesia Tahun 2010-2016. Jurnal Inspirasi Bisnis dan Manajemen. 2 (2): 167-176.

Sugeng, B. 2017. Manajemen Keuangan Fundamental. Deepublish. Yogyakarta.

Sugiyono. 2013. Metode Penelitian Kuantitatif, Kualitatif dan R\&D. Alfabeta. Bandung.

Sunaryo, D. 2019. Buku Ajar Manajemen Investasi dan Portofolio. Qiara Media. Surabaya.

Syafira, V.F. dan M. Kamal. 2016. Analisis Pengaruh Informasi Keuangan dan Ukuran Dewan terhadap Underpricing dengan Variabel Kontrol Ukuran Perusahaan (Studi Kasus pada Perusahaan yang Melakukan IPO di BEI Periode 2010-2015). Diponegoro Journal of Management. 5 (3): 2337-3792.

Tandelilin, E. 2017. Pasar Modal: Manajemen Portofolio \& Investasi. Kanisius. Yogyakarta.

Ulum, I. 2017. Intellectual Capital: Model Pengukuran, Framework Pengungkapan dan Kinerja Organisasi. UMM Press. Malang.

Utomo, A.H. dan A. Kurniasih. 2020. The Determinant of Underpricing Towards IPO Company at Indonesia Stock Exchange in 2019. Journal of Economics, Finance and Management Studies. 3 (8): 117-125. 
Wahyuningrum, S.R. 2020. Statistika Pendidikan (Konsep Data dan Peluang). Jakad Media Publishing. Surabaya.

Widhiastina, P. dan R. Prihatni. 2016. Pengaruh Return on Asset, Financial Leverage, dan Ukuran Perusahaan Terhadap Underpricing pada Perusahaan yang Melakukan Initial Public Offering (IPO) Di Bursa Efek Indonesia. Jurnal Ilmiah Wahana Akuntansi. 11 (2): 1-119.

Widyatuti, M. 2017. Buku Ajar Analisa Kritis Laporan Keuangan. Jakad Media Publishing. Surabaya. Yahoo Finance. 2020. https://finance.yahoo.com. 30 Oktober 2020 (07:34).

Zulfikar. 2016. Pengantar Pasar Modal dengan Pendekatan Statistika. Deepublish. Yogyakarta.

\section{Competing interests}

The authors declare that they have no competing interests.

\section{Funding}

Penelitian ini didanai oleh peneliti sendiri. 